\title{
Sustainable Agricultural Land Management in Garut Regency, West Java Province, Indonesia
}

DOI:10.36909/jer.ASSEEE.16089

\author{
Lia Warlina*, Syach Berriant Restu Pradana \\ Departemen Perencanaan Wilayah dan Kota, Universitas Komputer Indonesia \\ * Corresponding Author: lia.warlina@email.unikom.ac.id
}

\begin{abstract}
The high land conversion rate to other sectors has led the government to issue Law No. 41 in 2009 concerning Protection of Sustainable Agricultural Land (SAL). The study aims to identify the distribution of sustainable agricultural land uses and determine agricultural landuse changes from 2016 to 2019 and determine farmers' understanding of sustainable agricultural land control in the strategic area of Garut Regency. We overlaid the land use maps of Garut Regency in 2016 and 2019 and conducted a survey using an online questionnaire with a Google form. The research location is in five districts in Garut Regency. The results showed no land conversion in the area of existing sustainable agricultural land in Garut Regency. The total rice field area is 6,081 hectares, with about $24 \%$ is sustainable agricultural land. From 2016 to 2019, the rice field area decreased by 12 hectares. The farmers' awareness of SAL tends to be more likely aware of the sustainable agricultural land area, as many as $39 \%$ of farmers aware of sustainable agricultural land. The incentives given to farmers who control sustainable agricultural land are tax deduction, agricultural infrastructure supply, agricultural production facilities subsidies, and land certification facilities. The majority of the respondents are aware of these incentives. In conclusion, no sustainable agricultural land is converted, even though changes occur in non-sustainable agricultural land. The impact of this study is for recommendations to the government in sustainable agricultural land management.
\end{abstract}


Keywords: land conversion, agricultural land, Garut, sustainable.

\section{INTRODUCTION}

Land conversion is the change from one type of land use to another caused by the need for land areas for regional development. The most common land conversion is from agricultural to non-agricultural land due to industrialization (Gessese, 2018; Msofe et al., 2019; Warlina \& Guntara, 2019). The availability of agricultural land that is continuously converted will impact the agricultural activities of food crops.

Agricultural activities as an important sector for human life are very dependent on the availability of land. The availability of agricultural land is decreasing due to rapid development and population growth. The land is an essential factor in increasing the development of the agricultural sector (Critchley, W., \& Radstake, F. 2017, Maryati, et al. 2018). Indonesia's government regulates sustainable agricultural land to protect land availability for the development of the agricultural sector.

The regulation for controlling agricultural land in Indonesia is Law No. 41 of 2009 concerning Sustainable Agricultural Land (SAL) (Pemerintah Republik Indonesia, 2009). Sustainable agricultural land is areas designated land to be developed and protected consistently to provide national food security. The Government and Regional Governments carry out the control of Sustainable Agricultural Land through the provision of (a) incentives, (b) disincentives, (c) licensing mechanism, (d) protection, and (e) socialization.

Many countries are very concerned about the sustainability of the availability of land resources. Research in Hanoi, Vietnam, shows that changes in agricultural land due to urbanization have changed one-third of agricultural land into built-up areas in 14 years (Pham et al., 2015). Research in India shows that the planning and management of land resources are necessary for its sustainability. Therefore, limited and scarce agricultural land resources must be managed under the concept of sustainable development (Bhilare, A. 2013). Research on 
sustainable land use by identifying the land's ability with ecological and socioeconomic aspects valuation was conducted in Minoo Island, Iran (Kaffashi, S., \& Yavari, M. 2011).

Studies on sustainable agricultural land management or land conversions have been carried out in Indonesia's provinces, districts, and cities. Agricultural land conversion in West Bandung Regency shows changes in land use due to the growth of tourism areas. Research on sustainable agricultural land in West Sumatra focuses on policy and implications for local institutions or government (Noer et al., 2017). The research discusses sustainable agricultural land from political and legal aspects (Pitaloka, E. D. A. 2020 \& Stevens et al., 2020). Research on sustainable agricultural land is still at the policy or regulation aspect. Therefore, we need to conduct research on spatially sustainable agricultural land and from the farmer's perspective.

Garut Regency is one of the districts in West Java Province. The area of Garut Regency is $3,065.19 \mathrm{~km} 2$ with a population of around 2,284,220 people. The population density of Garut Regency is 745 people per square kilometer (Badan Pusat Statistik Kabupaten Garut, 2020).

Garut Regency is an agricultural area due to geological factors surrounded by mountains, valleys, and cliffs. This geological factor causes the land of the Garut Regency to be quite fertile for various food crops. The local government of Garut Regency regulates agricultural land with Regional Regulation No. 3 of 2016 concerning Sustainable Agricultural Land at the Local Activity Center (LAC) in Garut Regency (Pemerintah Kabupaten Garut. 2016).

In the Garut Regional Mid-Term Development Plan 2019-2024, the problems regarding land in Garut Regency are as follows: (a) low level of farmer welfare; (b) low quality of human resources in agriculture; (c) agricultural production is not optimal; (d) low added value and competitiveness of agricultural products; (e) inadequate agricultural supporting infrastructure; (f) conversion of agricultural land to non-agricultural land often occur; (g) very limited of the use of agricultural technology to support agriculture (Pemerintah Daerah Kabupaten Garut, 2019). 
According to the Garut Regency Spatial Plan 2011-2031, LAC in Garut Regency is in the district strategic area (DSA). DSA consists of 5 districts, namely Tarogong Kidul, Tarogong Kaler, Garut Kota, Banyuresmi, and Karangpawitan. LAC is the center of activities for industry and services that serve the district scale or several sub-districts. LAC is an activity center of the transportation node serving the regency or several sub-districts. The research objective was to determine the distribution and extent of existing SAL and identify changes in the SAL area in Garut Regency from 2016-2019 and examine the farmer's perspective on sustainable agricultural land management in DSA of Garut Regency.

\section{METHOD}

The location of the research project was in Garut Regency. The research area was in the district strategic area (DSA) consisting of five districts: District of Tarogong Kidul, Tarogong Kaler, Garut Kota, Bayuresmi, and Karang Pawitan (Figure 1). We conducted the research project from February to July 2020. The method of research was processing land use maps and direct surveys to the farmers.

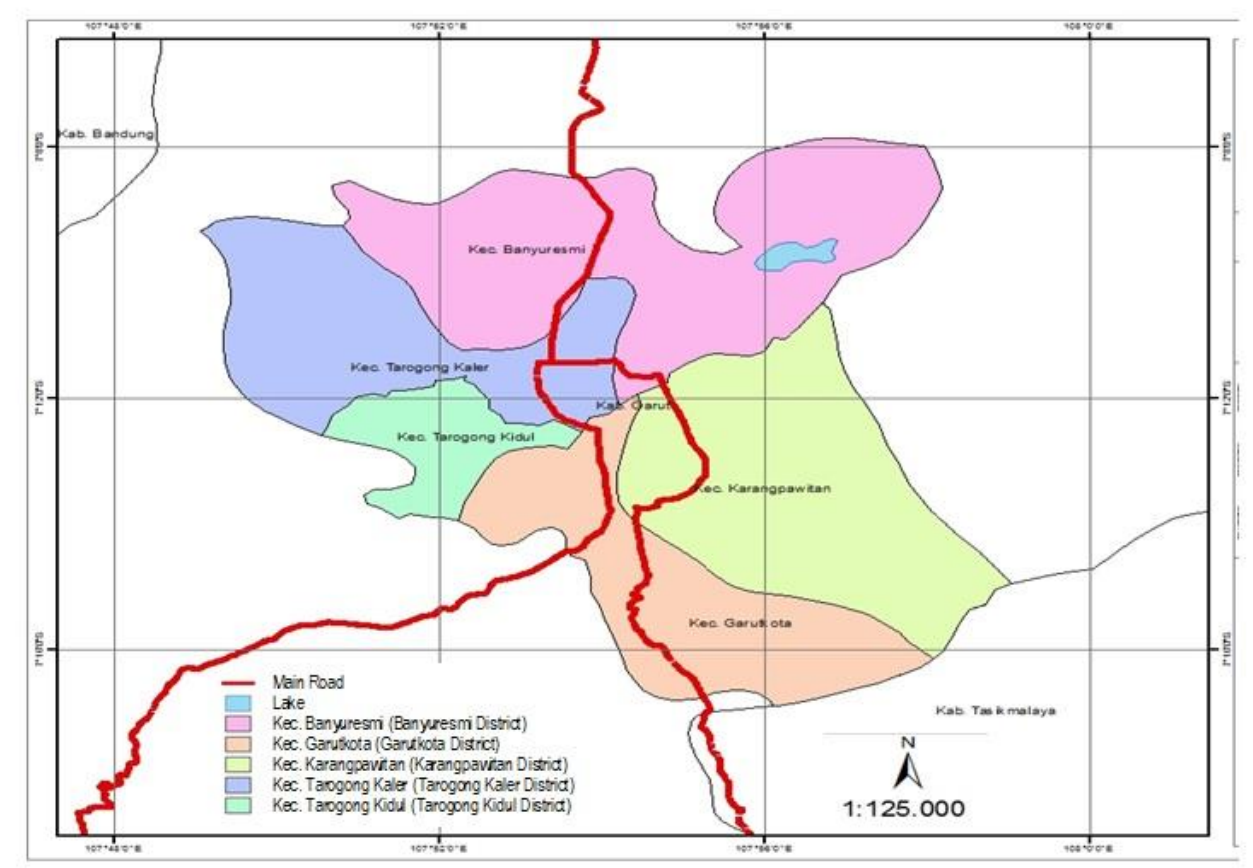

Figure 1 Research area in the district strategic area (DSA) in five Districts

The population, area, and population density of the study area are presented in Table 1 . Based on this table, the population density varies from about 230 people per $\mathrm{km}^{2}$ to more than 
5,000 people per $\mathrm{km}^{2}$. While in total all districts, the average population density is 745 people per $\mathrm{km}^{2}$.

Table 1 The population, area and population density of the research area (Badan Pusat Statistik Kabupaten Garut, 2020).

\begin{tabular}{|l|c|r|r|}
\hline \multicolumn{1}{|c|}{ Districts } & $\begin{array}{c}\text { Population } \\
\text { (persons) }\end{array}$ & Area $\left.\mathbf{( k m}^{\mathbf{2}}\right)$ & $\begin{array}{c}\text { Population density } \\
\left(\mathbf{p e r s o n s} / \mathbf{k m}^{\mathbf{2}}\right)\end{array}$ \\
\hline Tarogong Kidul & 104580 & 19.46 & 5374 \\
\hline Tarogong Kaler & 86460 & 50.57 & 1710 \\
\hline Garut Kota & 130320 & 27.71 & 4703 \\
\hline Banyuresmi & 82180 & 47.88 & 1716 \\
\hline Karangpawitan & 11990 & 52.07 & 230 \\
\hline
\end{tabular}

The data collection method is primary and secondary data. The direct survey was obtained by interviewing and distributing questionnaires to the respondents. The respondents were 100 farmers (Table 2). We asked respondents by Google form regarding their characteristics and their perspective on sustainable agricultural land in Garut Regency. In contrast, for secondary data, we collected from various related agencies. We applied an overlay technique to identify sustainable agricultural land changes. The analytical method used is the descriptive quantitative analysis method. The quantitative descriptive analysis method is used to describe farmers' awareness of SAL in Garut Regency.

Table 2 The number and characteristics of respondents.

\begin{tabular}{|l|c|c|c|}
\hline \multicolumn{1}{|c|}{ District } & $\begin{array}{c}\text { Landowner } \\
\text { farmers } \\
\text { (persons) }\end{array}$ & $\begin{array}{c}\text { Land renter } \\
\text { farmers } \\
\text { (person) }\end{array}$ & $\begin{array}{c}\text { Farmworkers } \\
\text { (persons) }\end{array}$ \\
\hline Tarogong Kidul & 5 & 3 & 7 \\
\hline Tarogong Kaler & 8 & 5 & 6 \\
\hline Garut Kota & 4 & 5 & 4 \\
\hline Banyuresmi & 10 & 5 & 8 \\
\hline Karangpawitan & 12 & 10 & 8 \\
\hline Total & 39 & 28 & 33 \\
\hline
\end{tabular}




\section{RESULTS AND DISCUSSION}

\section{Land Use in the District Strategic Area of Garut Regency}

The land use in the district strategic area (DSA) Garut Regency for 2019 is presented in

Figure 2. There are four types of land use categories: plantation, field crops, rice fields, and housing.

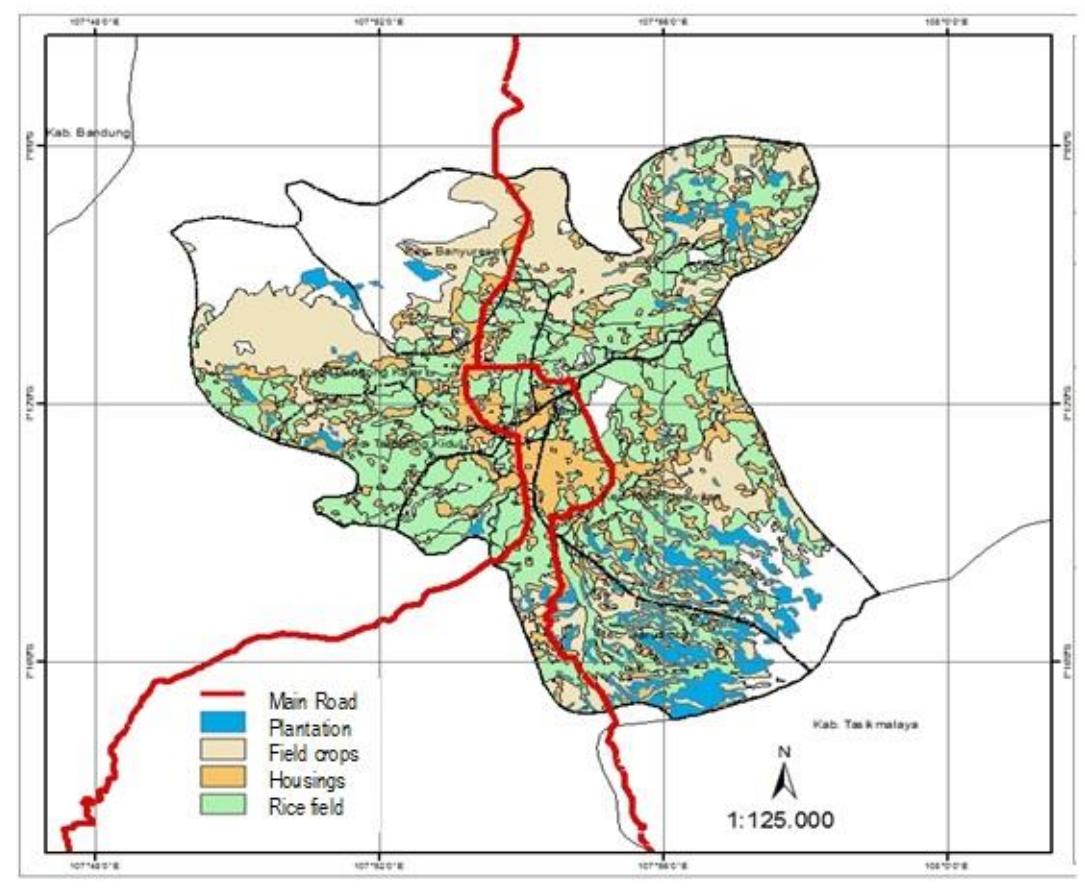

Figure 2 Land Use Map of the Study Area in 2019

Table 3 The land use of the Research Area in 2019.

\begin{tabular}{|c|c|c|c|c|}
\hline \multirow{2}{*}{ Districts } & \multicolumn{4}{|c|}{ Land Use (Hectares) } \\
\cline { 2 - 5 } & Plantation & Field Crops & Rice Field & \multirow{2}{*}{ Housings } \\
\hline Tarogong Kidul & 37 & 49 & 955 & 905 \\
\hline Tarogong Kaler & 129 & 2747 & 960 & 1221 \\
\hline Garut Kota & 557 & 366 & 1025 & 823 \\
\hline Banyuresmi & 211 & 2065 & 1177 & 1335 \\
\hline Karangpawitan & 634 & 1436 & 1964 & 1173 \\
\hline
\end{tabular}




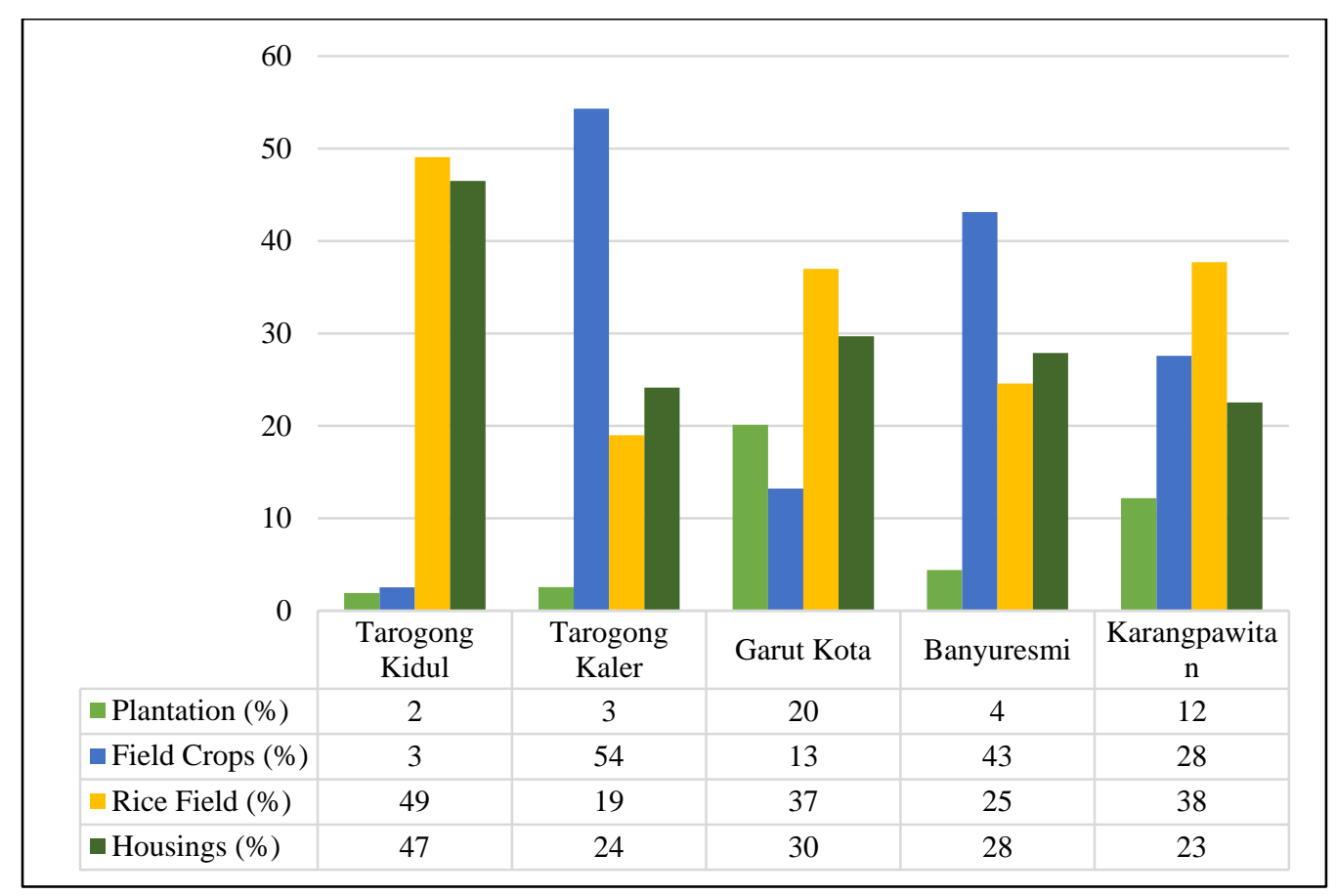

Figure 3 The land use of the Strategic Area in 2019 (in percentage).

The types of land use housings include types of land uses for trade and industry because the research area in Garut Regency is dominated by agriculture. Table 3 and Figure 3 illustrate the land use composition in the study area. In Tarogong Kidul District, the dominant land use types are rice fields and housings. Meanwhile, land use in Tarogong Kaler and Banyuresmi Districts is dominated by field crops. In the Districts of Garut Kota and Karangpawitan, the percentage of land use distribution is relatively even for each type. This condition can be caused by Garut Regency Gross Regional Domestic Product based on the industry during 2016-2020, agriculture contributed around 38\%, followed by trade sector around $19 \%$ and manufacturing industry around 8\% (Badan Pusat Statistik Kabupaten Garut, 2021).

\section{Area and Distribution of Sustainable Agricultural Land (SAL) in Garut Regency}

The area of rice fields in the strategic area of Garut Regency is 6,081 hectares (Table 4). Figure 4 presents a distribution map of sustainable agricultural land. The most extensive rice field area is in Karangpawitan District, with 1,964 hectares. The smallest land area is in Tarogong Kidul District, with a rice field area of 955 hectares. Meanwhile, the largest SAL is 
in Garut Kota (42\%), and the smallest is in Tarogong Kaler District (12\%), with the total percentage of SAL to rice field area is $24 \%$.

Table 4 The Area of Sustainable Agricultural Land in Garut Regency.

\begin{tabular}{|l|c|c|c|}
\hline \multicolumn{1}{|c|}{ District } & $\begin{array}{c}\text { Area of the rice } \\
\text { field (hectares) }\end{array}$ & $\begin{array}{c}\text { Area of SAL } \\
\text { (hectares) }\end{array}$ & Area of SAL (\%) \\
\hline Tarogong Kidul & 955 & 274 & 29 \\
\hline Tarogong Kaler & 960 & 116 & 12 \\
\hline Garut Kota & 1025 & 432 & 42 \\
\hline Banyuresmi & 1177 & 249 & 21 \\
\hline Karangpawitan & 1964 & 366 & 19 \\
\hline Total & 6081 & 1437 & 24 \\
\hline
\end{tabular}

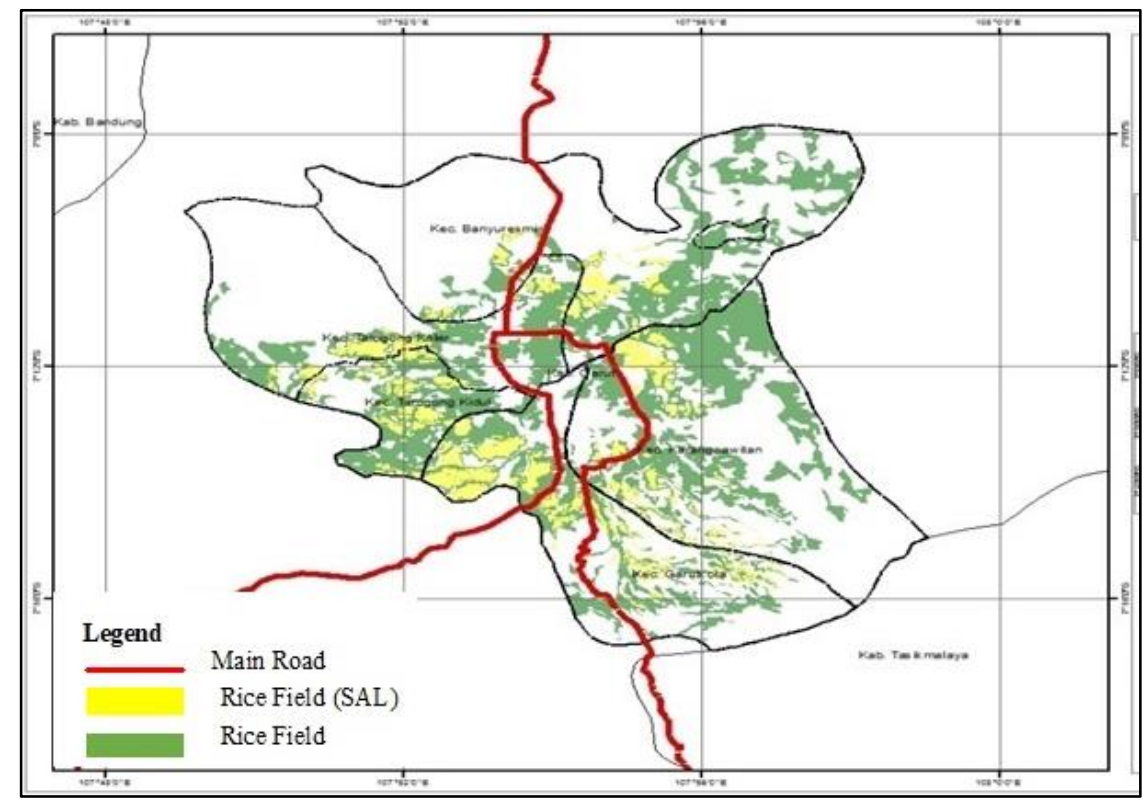

Figure 4 Land Use Map of Rice Field as Sustainable Agricultural Land (SAL) in Garut Regency.

Overlay of land use maps in 2019 and 2016 produces information on land-use changes for rice field areas. There are about 12 hectares in Tarogong Kidul Subdistrict, which have changed from rice fields to housing and sport center areas. There are no sustainable agricultural land areas that have changed into other land use (Figure 5, Table 5). The relatively small land-use change in Garut Regency aligns with the West Java Province's 
research results. Districts in the southern part of West Java province, including the Garut Regency, have not decreased sustainable agricultural land (Maryati et al., 2018).

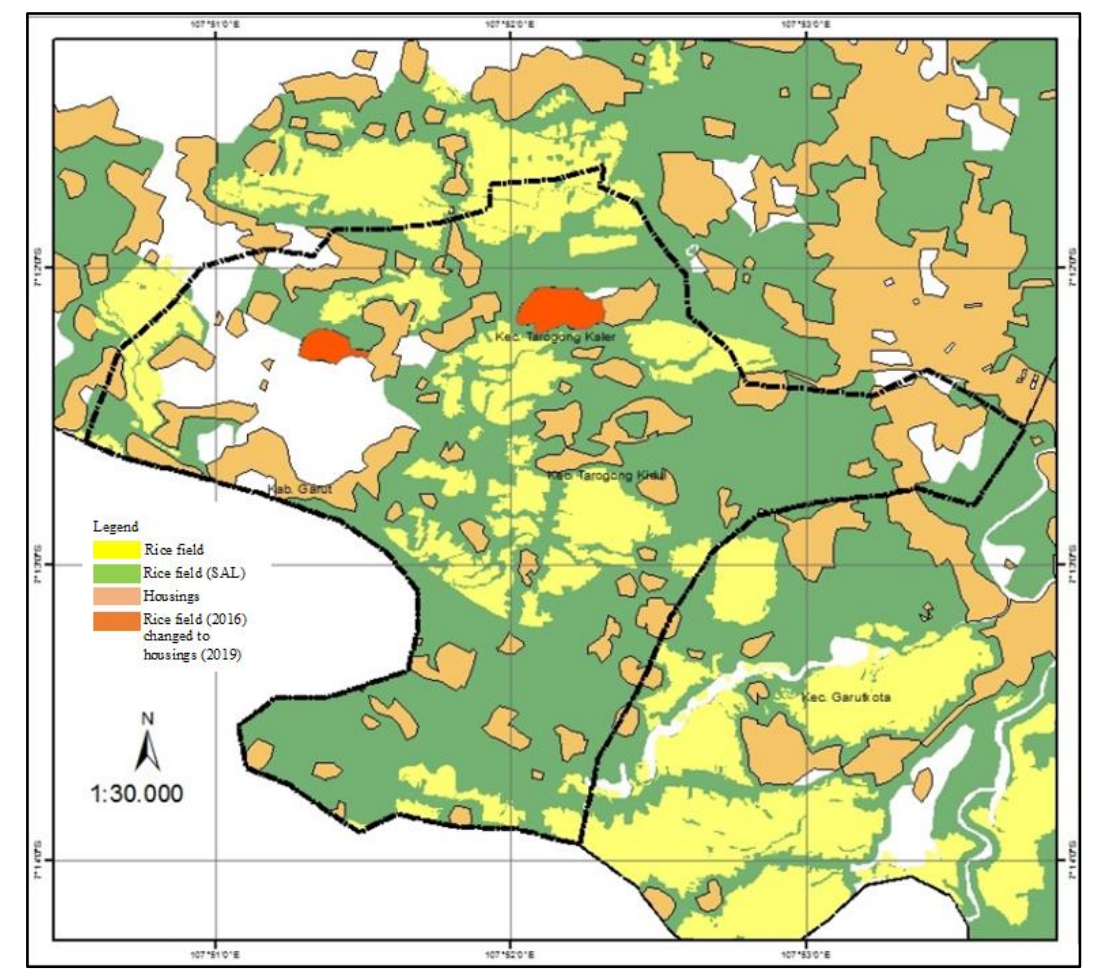

Figure 5 Land Use Change Map and Sustainable Agricultural Land (SAL) in Garut Regency.

Table 5. Land-use change area in Garut Regency (2016 -2019).

\begin{tabular}{|l|c|c|c|}
\hline \multicolumn{1}{|c|}{ District } & $\begin{array}{c}\text { Rice field area in } \\
\mathbf{2 0 1 6} \text { (hectares) }\end{array}$ & $\begin{array}{c}\text { Rice field area } \\
\text { in 2019 } \\
\text { (hectares) }\end{array}$ & $\begin{array}{c}\text { Change areas } \\
\text { (hectares) }\end{array}$ \\
\hline Tarogong Kidul & 967 & 955 & 12 \\
\hline Tarogong Kaler & 960 & 960 & 0 \\
\hline Garut Kota & 1025 & 1.025 & 0 \\
\hline Banyuresmi & 1177 & 1.177 & 0 \\
\hline Karangpawitan & 1.964 & 1.964 & 0 \\
\hline
\end{tabular}

In the strategic area of Garut district, there has been no change in land use for sustainable agricultural land for three years, indicating that the regulations have been implemented correctly. The results of the study are in line with conditions in Serang Regency. A study on implementing a sustainable agricultural land policy through the Serang Regency Spatial Plan 
instrument shows that SAL is implemented well when planning for the protection of agricultural land is in line with the spatial plan (Darma and Silfiana, 2019). Moreover, the success of implementing sustainable agricultural land protection is also determined by an accurate mapping method for establishing local regulations (Hatmanto and Setyono, 2019).

\section{Farmer's Awareness Regarding Sustainable Agricultural Land Management in Garut}

\section{Regency}

The farmers who know about sustainable agricultural land are 39 out of 100 respondents. With detail, $18 \%$ are landowners, $8 \%$ are land renters, and $13 \%$ are farmworkers (Table 6). The number of landowners' farmers who know sustainable agricultural land location is more significant than land renter farmers because landowners will be more concerned with their land condition. As happened in Pakistan, land ownership is a factor in land management (Rajpar et al., 2019).

Table 6 Farmer's awareness regarding SAL in Garut Regency.

\begin{tabular}{|c|c|c|}
\hline Farmer's Characteristics & $\begin{array}{c}\text { Farmers aware of } \\
\text { SAL in Garut } \\
\text { Regency (persons) }\end{array}$ & $\begin{array}{c}\text { Farmers do not seem } \\
\text { aware of SAL in } \\
\text { Garut Regency } \\
\text { (persons) }\end{array}$ \\
\hline Landowners & 18 & 23 \\
\hline Land renters & 8 & 18 \\
\hline Workers & 13 & 20 \\
\hline Total & 39 & 61 \\
\hline
\end{tabular}

Farmers who know sustainable agricultural land are asked again about the area or location of the land. The result is that 14 people know the location and area of sustainable agricultural land. In comparison, the remaining 25 people do not know the location of sustainable agricultural land (Table 7). 
Table 7 Farmer's awareness regarding the location of SAL in Garut Regency

\begin{tabular}{|c|c|c|}
\hline Farmer's Characteristics & $\begin{array}{c}\text { Farmers know about } \\
\text { SAL areas in Garut } \\
\text { Regency (persons) }\end{array}$ & $\begin{array}{c}\text { Farmers do not know } \\
\text { about SAL areas in } \\
\text { Garut (persons) }\end{array}$ \\
\hline Landowners & 9 & 12 \\
\hline Land renters & 2 & 4 \\
\hline Workers & 3 & 9 \\
\hline Total & 14 & 25 \\
\hline
\end{tabular}

Land that has been designated as sustainable agricultural land is protected and is prohibited from being converted. The conversion of sustainable agricultural land for the public interest can be carried out with the following conditions: a strategic feasibility study is carried out; compiled a land conversion plan; freed ownership rights from the owner, and provided replacement of the converted land (Pemerintah Republik Indonesia. 2009) (Handayani et al., 2018). To protect sustainable agricultural land, the government provides incentives, namely tax deduction, agricultural infrastructure supply, agricultural production facilities subsidies, and land certification facilities. We surveyed 100 respondents for their knowledge about incentives for land management. The results of this survey are shown in Table 8 .

Table 8 Farmer's awareness regarding land management incentives in Garut Regency

\begin{tabular}{|c|c|c|}
\hline $\begin{array}{c}\text { Land management } \\
\text { incentives }\end{array}$ & $\begin{array}{c}\text { Farmers aware of land } \\
\text { management incentives } \\
\text { (percentage) }\end{array}$ & $\begin{array}{c}\text { Farmers seem not aware } \\
\text { of land management } \\
\text { incentives (percentage) }\end{array}$ \\
\hline Tax deduction of land & $73 \%$ & $37 \%$ \\
\hline $\begin{array}{c}\text { Agricultural infrastructure } \\
\text { supply from local } \\
\text { government }\end{array}$ & $93 \%$ & $7 \%$ \\
\hline $\begin{array}{c}\text { Agricultural production } \\
\text { facilities subsidies }\end{array}$ & $89 \%$ & $11 \%$ \\
\hline Land certification facilities & $65 \%$ & $35 \%$ \\
\hline
\end{tabular}

In general, farmers understand that the government helps farmers in managing agricultural land. Meanwhile, very few farmers understand the concept of sustainable agricultural land. However, about $97 \%$ of respondents understand that the local government of Garut Regency provides incentives for agricultural production facilities. Research on farmers' perceptions of 
sustainable agricultural land about land degradation has been carried out in Ethiopia; the results show that socioeconomic and institutional factors significantly influence perceptions (Tesfahunegn, G. B. 2019). Similar research with the farmers' livelihood assets relates to the adoption of sustainable land management show that most farmers use manure for soil fertility replenishment (Belay, M., \& Bewket, W. 2013).

\section{CONCLUSION}

There was no land conversion in the area of existing sustainable agricultural land in Garut Regency from 2016 to 2019 . However, there is a change of rice field area about 12 hectares into housing and sports center area. The total agricultural land area is 14,312 hectares, with 6,081 hectares of rice fields. The SAL area in Garut Regency is 1,437 hectares. The largest rice field area is Garut Kota Subdistrict (432 hectares), and the smallest is Tarogong Kaler (116 hectares). The farmers' awareness of sustainable agricultural land in Garut Regency tends to be more likely aware of the sustainable agricultural land area. As many as $39 \%$ of farmers aware of sustainable agricultural land. However, only $14 \%$ of farmers know about the location of sustainable agricultural land in Garut Regency. The incentives given to farmers who control sustainable agricultural land are agricultural infrastructure supply, agricultural production facilities subsidies, and land certification facilities. The majority of the respondents are aware of these incentives.

\section{ACKNOWLEDGMENT}

We thank the Office of Spatial Planning and Human Settlement Garut Regency. They provided data that much helped this research. However, the institution may not agree with all of the interpretations/conclusions of this article. 


\section{REFERENCES}

Badan Pusat Statistik Kabupaten Garut, 2020. Kabupaten Garut Dalam Angka 2020 (Garut Regency in Figures 2020). Badan Pusat Statistik, Kabupaten Garut.

Badan Pusat Statistik Kabupaten Garut, 2021. Produk Domestik Regional Bruto Kabupaten Garut menurut Lapangan Usaha 2016-2020. Badan Pusat Statistik Kabupaten Garut.

Belay, M., \& Bewket, W. 2013. Farmers' livelihood assets and adoption of sustainable land management practices in north-western highlands of Ethiopia. International Journal Environment Studies. 70: 284-301

Bhilare, A. 2013. Sustainable Agriculture and Land Management Research. India Publication. 4: 881-6.

Critchley, W., \& Radstake, F. 2017. Sustainable Land Management in Asia: Introducing the Landscape Approach (Metro Manila: Asian Development Bank)

Darma, B.A., Silfiana, S., 2019. Policy evaluation of peraturan daerah No. 5 tahun 2014 on land protection of sustainable food farming in Banten Province. J. Kebijakan Pembangunan Daerah. 3: 33-48

Gessese, B.H., 2018. Impact of Land Use/Land Cover Change on Rural Communities Livelihood of Ethiopia 6: 8.

Handayani, S. W., Fauzan, M., \& Nasihuddin, A. A. 2018. Conversion of Agricultural Land Policy in Indonesia Proceedings of the 5th International Conference on Community Development (AMCA 2018). 2018 3rd International Conference on Education, Sports, Arts and Management Engineering (ICESAME 2018) (Quezon City, Philippines: Atlantis Press) 
Hatmanto, T., Setyono, J.S., 2019. Implementasi Kebijakan Lahan Pertanian Pangan Berkelanjutan (LP2B) Melalui Penggunaan Peta Spasial Studi Kasus di Kabupaten Temanggung, Provinsi Jawa Tengah. SNG 3: 735.

Kaffashi, S., \& Yavari, M. 2011. Land-use planning of Minoo Island, Iran, towards sustainable land-use management. International Journal Sustainable Development World Ecol. 18: 304-315

Maryati, S., Humaira, A. N. S., \& Pratiwi, F. 2018. Spatial pattern of agricultural land conversion in West Java Province. IOP Conf. Ser. Earth Environ. Sci. 131: 012034

Msofe, N., Sheng, L., Lyimo, J., 2019. Land Use Change Trends and Their Driving Forces in the Kilombero Valley Floodplain, Southeastern Tanzania. Sustainability 11: 505.

Noer, M., Hakimi, R., \& Reza, M. 2017. Land Policy for Sustainable Agricultural Land and its Implementation: Experiences from West Sumatra. International Journal Advanced Science Engineering Information Technology. 7: 2088-5334

Pemerintah Kabupaten Garut. 2016. Peraturan Daerah Kabupaten Garut Nomor 3 Tahun 2016 Tentang Lahan Pertanian Pangan Berkelanjutan Pada Pusat Kegiatan Lokal Perkotaan Garut di Kabupaten Garut

Pemerintah Republik Indonesia. 2009. Undang-undang Republik Indonesia Nomor 41 Tahun 2009 tentang Perlindungan lahan pertanian pangan berkelanjutan

Pemerintah Daerah Kabupaten Garut, 2019. Rencana Pembangunan Jangka Menengah Daerah Kabupaten Garut Tahun 2019-2024.

Pham, V.C., Pham, T.-T.-H., Tong, T.H.A., Nguyen, T.T.H., Pham, N.H., 2015. The conversion of agricultural land in the peri-urban areas of Hanoi (Vietnam): patterns in space and time. Journal of Land Use Science 10: 224-242. 
Pitaloka, E. D. A. 2020. Kebijakan Perlindungan Lahan Pertanian Pangan Berkelanjutan Dalam Dimensi Politik Hukum Penataan Ruang, Jurnal IUS Kajian Hukum Dan Keadilan 8: 49

Rajpar, H., Zhang, A., Razzaq, A., Mehmood, K., Pirzado, M. B., \& Hu, W. 2019. Agricultural Land Abandonment and Farmers' Perceptions of Land Use Change in the Indus Plains of Pakistan: A Case Study of Sindh Province Sustainability, 11: 4663.

Stevens, C. J., Greif, A., \& Bouma, D. 2020. Do companies care about sustainable land governance? An empirical assessment of company land policies. International Journal Sustainable Development World Ecol. 27: 334-48.

Tesfahunegn, G. B. 2019. Farmers' perception on land degradation in northern Ethiopia: Implication for developing sustainable land management. Social Science Journal. 56: $268-87$

Warlina, L., Guntara, R., 2019. Agricultural land-use change into the Lembang Sub-district, West Bandung Regency, West Java Province, Indonesia. IOP Conf. Ser.: Mater. Sci. Eng. 662: 042016. 